\title{
Megadroughts in North America: placing IPCC projections of hydroclimatic change in a long-term palaeoclimate context
}

\author{
EDWARD R. COOK, ${ }^{1 *}$ RICHARD SEAGER, ${ }^{1}$ RICHARD R. HEIM JR, ${ }^{2}$ RUSSELL S. VOSE, \\ CELINE HERWEIJER ${ }^{3}$ and CONNIE WOODHOUSE ${ }^{4}$ \\ ${ }^{1}$ Lamont-Doherty Earth Observatory, Palisades, New York, USA \\ ${ }^{2}$ NOAA/NESDIS/National Climatic Data Center, Asheville, North Carolina, USA \\ ${ }^{3}$ Risk Management Solutions Ltd, London, UK \\ ${ }^{4}$ University of Arizona, Tucson, Arizona, USA
}

Cook, E. R., Seager, R., Heim Jr, R. R., Vose, R. S., Herweijer, C. and Woodhouse, C. Megadroughts in North America: placing IPCC projections of hydroclimatic change in a long-term palaeoclimate context. J. Quaternary Sci., (2009). ISSN 0267-8179.

Received 16 November 2008; Revised 8 May 2009; Accepted 10 May 2009

\begin{abstract}
IPCC Assessment Report 4 model projections suggest that the subtropical dry zones of the world will both dry and expand poleward in the future due to greenhouse warming. The US Southwest is particularly vulnerable in this regard and model projections indicate a progressive drying there out to the end of the 21 st century. At the same time, the USA has been in a state of drought over much of the West for about 10 years now. While severe, this turn of the century drought has not yet clearly exceeded the severity of two exceptional droughts in the 20th century. So while the coincidence between the turn of the century drought and projected drying in the Southwest is cause for concern, it is premature to claim that the model projections are correct. At the same time, great new insights into past drought variability over North America have been made through the development of the North American Drought Atlas from tree rings. Analyses of this drought atlas have revealed past megadroughts of unprecedented duration in the West, largely in the Medieval period about 1000 years ago. A vastly improved Living Blended Drought Atlas (LBDA) for North America now under development reveals these megadroughts in far greater detail. The LBDA indicates the occurrence of the same Medieval megadroughts in the West and similar-scale megadroughts in the agriculturally and commercially important Mississippi Valley. Possible causes of these megadroughts and their implications for the future are discussed. Copyright (C) 2009 John Wiley \& Sons, Ltd.
\end{abstract}

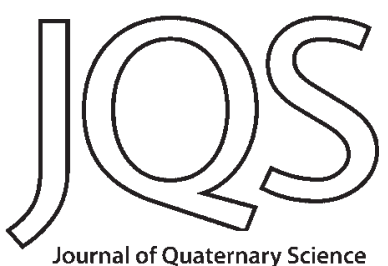

KEYWORDS: megadrought; North America; IPCC; hydroclimatic change; palaeoclimate.

\section{Introduction}

The Intergovernmental Panel on Climate Change (IPCC) recently released its Fourth Assessment Report (AR4), 'Climate Change 2007' on the causes, impacts and possible response strategies to future climate change. In the Working Group I report on 'The Physical Science Basis' (IPCC, 2007), a detailed examination of model-based projections of future global climate change was conducted (Meehl et al., 2007). Among those was a multi-model assessment of projected changes in precipitation and surface water from 1999 to 2099 based on the medium A1B forcing scenario that increases greenhouse gas

* Correspondence to: E. R. Cook, Lamont-Doherty Earth Observatory, Palisades, NY 10964, USA.

E-mail: drdendro@Ideo.columbia.edu emissions until 2050 and gradually decreases them thereafter (Nakicenovic and Swart, 2000).

Figure 1 shows these results mapped globally as differences in annual means for 2080-2099 relative to 1980-1999. Each map shows a progressive drying in the subtropical latitudes that is especially evident over southern North America and the Mediterranean region of the Northern Hemisphere. The physical basis for these projected changes is described in Held and Soden (2006) and Seager et al. (2007b) as being associated with, first, a drying of the already dry subtropics and a moistening of the wetter deep tropics and mid-latitudes, as a consequence of an intensification of the atmospheric hydrological cycle and, second, a poleward expansion of the Hadley Cell and poleward shift of the mid-latititude storm tracks. Both mechanisms are a robust response of the atmosphere to greenhouse gas-induced warming. Progressive drying of dry subtropical areas and a poleward expansion of these zones explain the pattern of enhanced aridity projected for the future in Fig. 1. 
(a)

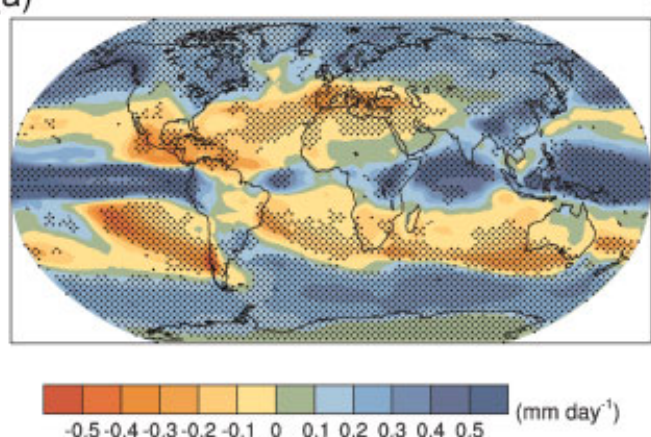

(c)

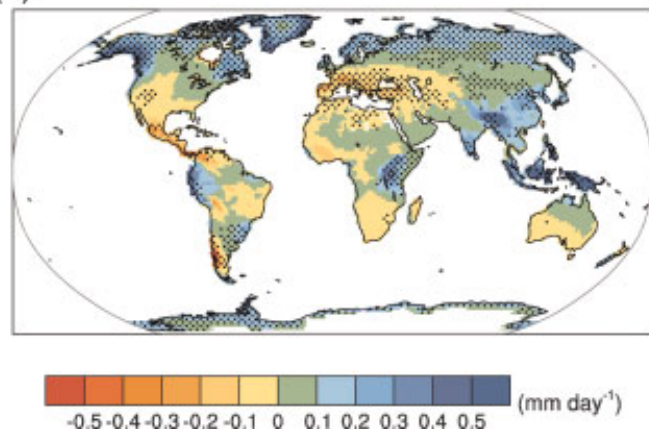

(b)

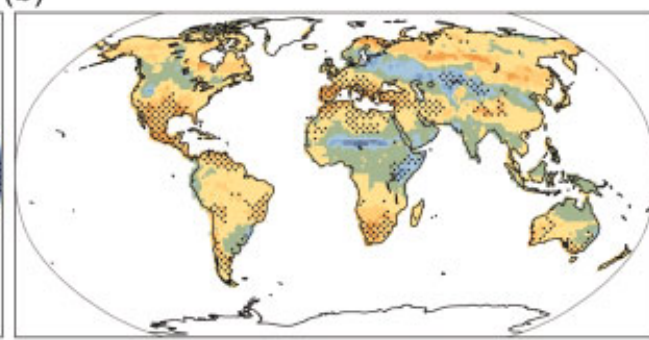

$\frac{1}{-25}-20-15-10-5 \quad 0 \quad 5 \quad 10 \quad 15 \quad 20 \quad 25$

$(\%)$

(d)

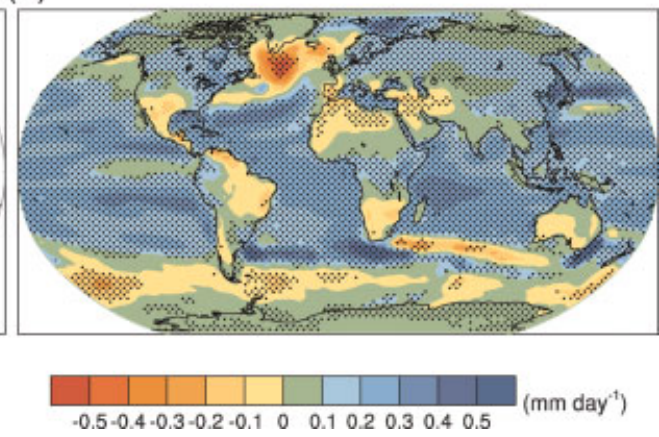

Figure 1 Multi-model mean changes in (a) precipitation $\left(\mathrm{mm} \mathrm{d}^{-1}\right)$, (b) soil moisture content $(\%)$, (c) runoff $\left(\mathrm{mm} \mathrm{d}^{-1}\right)$ and $(\mathrm{d})$ evaporation $\left(\mathrm{mm} \mathrm{d} \mathrm{d}^{-1}\right)$. To indicate consistency in the sign of change, regions are stippled where at least $80 \%$ of models agree on the sign of the mean change. Changes are annual means for the period 2080-2099 relative to 1980-1999. Soil moisture and runoff changes are shown at land points with valid data from at least 10 models. From Meehl et al. (2007). Figure courtesy of IPCC (http://www.ipcc.ch/graphics/graphics/ar4-wg1/jpg/fig-10-12.jpg)

Seager et al. (2007b) went one step further and examined the same IPCC A1B model runs for a restricted region of North America that showed strong evidence of projected drying: 'the Southwest' (all land between $95-125^{\circ} \mathrm{W}$ and $25-40^{\circ} \mathrm{N}$ ). This region includes both the southwestern USA and northern Mexico. Figure 2 shows the summary plots of modelled precipitation $(P)$, evaporation $(E)$, and the difference between them $(\mathrm{P}-\mathrm{E})$ averaged over the Southwest for each year from 1900 to 2098 across all models. All three variables indicate progressive drying over the region, especially after 1990. This finding prompted Seager et al. (2007b) to suggest that the transition to a more arid climate should already be under way in the Southwest - if the models are correct.
At this time, we do not know with any certainty if the model projections examined by Seager et al. (2007b) are correct. Indeed, the emissions scenarios used in these studies are a decade old now and, in fact, actual emissions over these years have exceeded the IPCC worst-case scenarios. Clearly, emissions scenarios and simulations with actual, historical, trace gas concentrations need to be updated. However, despite these uncertainties and coincidental or not, climate over the western USA ('the West' - defined here as the coterminous USA west of $95^{\circ} \mathrm{W}$ ) does appear to have entered a protracted period of elevated aridity that began around 1999. Because this drought mostly occupies the beginning decade of the $21 \mathrm{st}$ century, we refer to it here as the 'turn of the century drought'

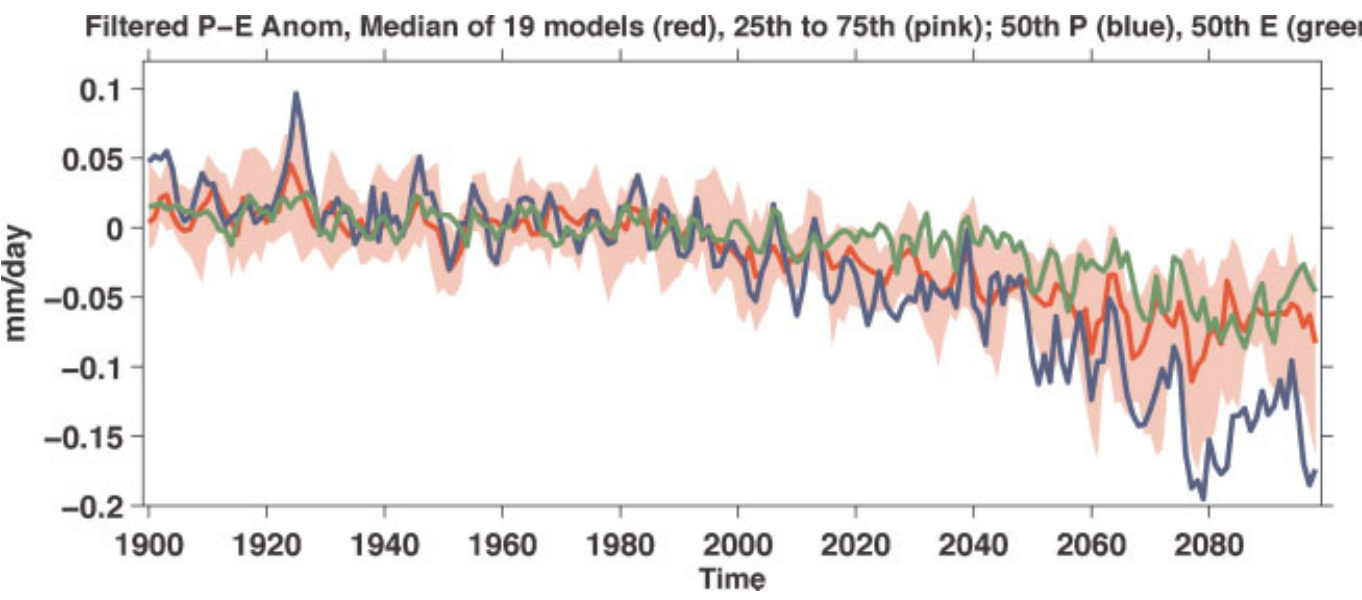

Figure 2 Modelled changes in annual mean precipitation minus evaporation (P-E) over the 'the Southwest' averaged over an ensemble of 19 separate models using the same A1B forcing scenario. The median (red line) and 25th and 75th percentiles (pink shading) of the P-E distribution among the 19 models are shown, as are the ensemble medians of P (blue line) and E (green line) for the period common to all models (1900-2098). From Seager et al. (2007b) 


\section{Turn of the 21st Century Drought in the United States}

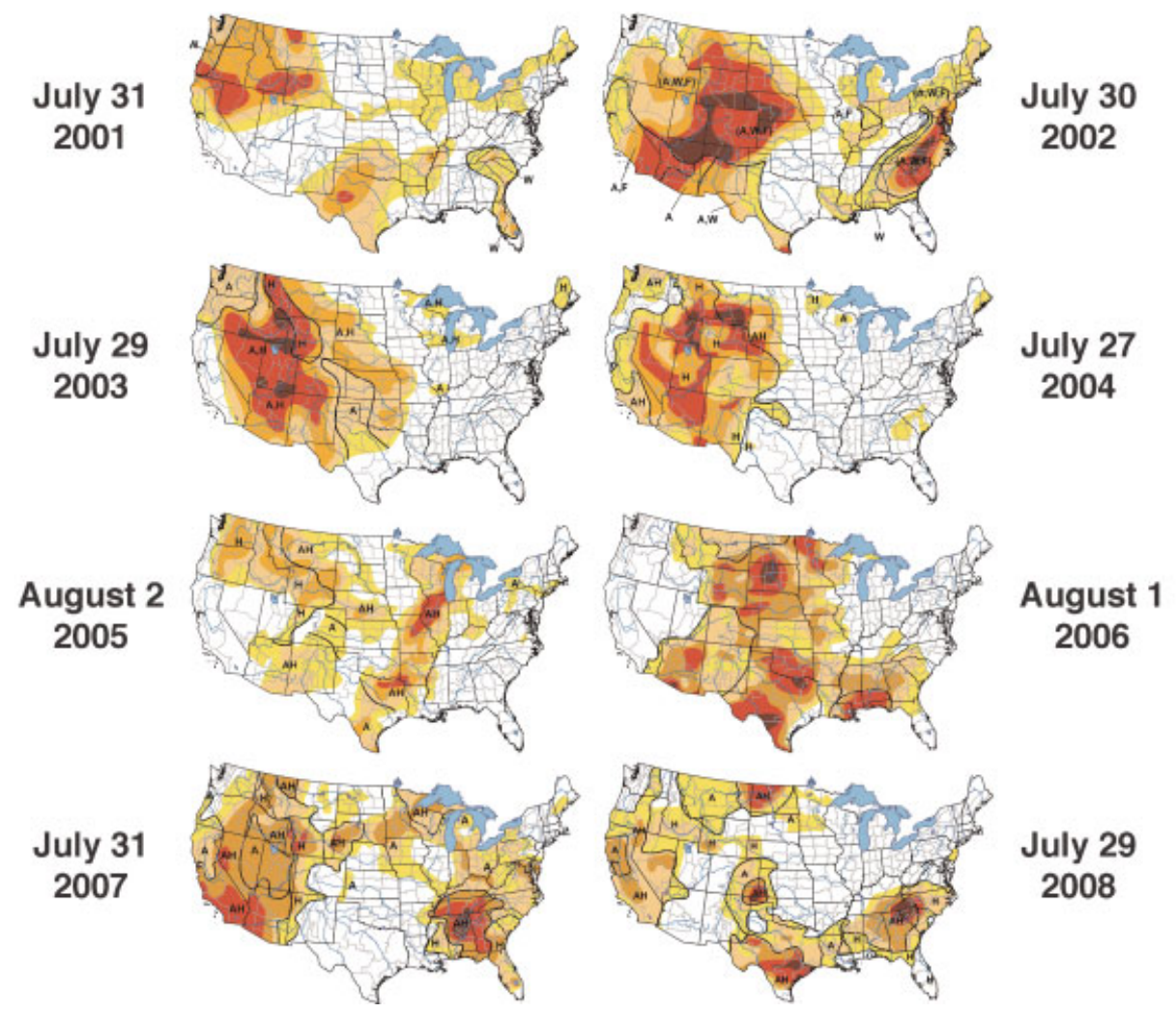

Figure 3 Mid-summer drought maps for the USA since 2001. These maps show the complex spatial patterns of drought that make up the 21 st-century drought. While its intensity has waxed and waned (cf. the 2002 and 2005 maps), the drought has not truly ended yet. Figure created from downloaded US Drought Monitor maps (http://www.drought.unl.edu/dm/monitor.html)

(sensu MacDonald et al., 2008). The spatial impact of this drought over the USA for the mid-summer season is shown since 2001 (Fig. 3; maps from the US Drought Monitor; Svoboda et al., 2002). As many large-scale droughts tend to be, it is a spatially complex pattern that can change rapidly from year to year (cf. 2006 and 2007). Indeed, a serious drought developed in the US Southeast in 2006 and has persisted since, although this is not an area that is confidently expected to dry as a consequence of global warming (see Fig. 1). The West, however, for the most part, has been in an overall state of drought up to and including the 2008 summer. Here, the observations presently available are at least consistent with the climate projections due to greenhouse gas forcing described by Meehl et al. (2007) and Seager et al. (2007b).

\section{How does the turn of the century drought compare to 20th-century droughts?}

Given the reasonably strong consistency between the observations and model projections during the first decade of the new millennium, it is useful to place the 21 st-century drought in a longer-term perspective. To begin, how does the 21 st-century drought compare to earlier severe droughts in the instrumental record for North America? For the 20th century, two large-scale droughts of notable intensity and duration occurred: the Dust Bowl drought of the 1930s and the southern Great Plains/ Southwest drought of the 1950s (McGregor, 1985; Andreadis et al., 2005; Seager et al., 2005; Stahle et al., 2007). These are useful benchmark events for placing the 21 st-century drought in its modern instrumental period context.
Based on intensity and spatial coverage, the most severe 21 stcentury drought year occurred in 2002, with more than $50 \%$ of the coterminous USA under moderate to severe drought conditions (Lawrimore and Stephens, 2003). To compare this year with others in the 20th century, gridded instrumental Palmer Drought Severity Indices (PDSI; Palmer, 1965; Heim, 2002), used by Cook et al. (2004) for tree ring reconstruction were examined back to 1900 over the USA. The number of grid points of summer PDSI that exceeded a drought threshold of PDSI $<-1.0$ (incipient or more severe drought; Palmer, 1965) was tallied for each year and expressed as a percentage of the total number of grid points to produce a Drought Area Index (DAl; Mitchell et al., 1979; Cook et al., 1997, 2004). For 2002, the DAl calculated this way was $59 \%$, a number quite comparable to the $>50 \%$ area reported by Lawrimore and Stephens (2003). In contrast, the Dust Bowl drought in 1934 and the Great Plains/Southwest drought in 1954 covered $77 \%$ and $62 \%$ of the USA, respectively. Both exceed the area covered by the 21 st-century drought in 2002 . Thus, for the USA as a whole, the 2002 drought year was not unprecedented. These comparisons do not change much if the DAI comparisons are restricted to the West. When this is done, the DAls for 1934 , 1954 and 2002 are 93\%, 75\%, and 82\%, respectively. The 2002 drought year now exceeds 1954, but not 1934, for the West. Thus the 1934 Dust Bowl drought year remains the single-year benchmark in terms of severity and spatial extent of drought over the USA and the West since 1900, as measured by the PDSI.

The duration of droughts is more difficult to estimate precisely owing to the complexity of drought variability over space and time (cf. the Fig. 3 maps) and because inter-annual variability tends to punctuate otherwise dry multi-year intervals with occasional wet years. See Cole et al. (2002), Fye et al. (2003), Andreadis et al. (2005) and Herweijer et al. (2007) for discussions on how to estimate drought duration over the USA. 
Suffice to say, there is no unique solution for calculating drought duration. Thus Stahle et al. (2007) estimated that the Dust Bowl drought lasted from 1929 to 1940 (12 years) and the southern Great Plains/Southwest drought from 1951 to 1964 (14 years). In contrast, Seager et al. (2005) defined the Dust Bowl and southern Great Plains/Southwest droughts as occurring from 1932 to 1939 (8 years) and from 1948 to 1957 (10 years), and Andreadis et al. (2005) estimated the same two droughts as occurring from 1932 to 1938 (7 years) and from 1950 to 1957 (8 years). The 21st-century drought began around 1999 and is still in progress, so its current 10-year duration must be viewed as comparable to the previous two droughts within the limits of how duration is estimated. Should the current drought persist, and perhaps even intensify as suggested by model projections (Seager et al., 2007b), the 21st-century drought may yet emerge as an unprecedented event compared to the exceptional droughts of the 20th century. Only time will tell in this regard.

\section{How does the 21st-century drought compare to droughts over the past millennium?}

There is abundant evidence now that some droughts in North America prior to the 20th century were remarkably more severe compared to anything we have experienced since that time. Perhaps the most famous example is the 'Great Drouth' (sic) of AD 1276-1299 described by A. E. Douglass $(1929,1935)$ as the likely cause of the abandonment of Anasazi cliff dwellings across the Colorado Plateau. This 24-year drought easily exceeds the duration of the worst 20th-century droughts described earlier. Weakley (1965) found evidence for an even longer 38-year drought lasting from AD 1276 to 1313 in Nebraska that may have been a more prolonged northerly extension of the 'Great Drouth'. Whether or not these droughts are manifestations of the same event, they pale in comparison to two extraordinary droughts discovered by Stine (1994) in California that lasted more than two centuries before AD 1112 and more than 140 years before AD 1350 (each based on many calibrated radiocarbon dates with approximate 50-year standard deviations). The durations of these 'Stine droughts' were based on the number of annual rings in relic tree stumps rooted in present-day lakes, marshes and streams on the east side of the Sierra Nevada mountains, solid first-order evidence of the minimum duration of each megadrought because the sampled tree species cannot live with their roots in water. Each of these 'megadroughts' (by modern standards droughts of unusually long duration that typically exceed those observed in the instrumental records; Woodhouse and Overpeck, 1998; Stahle et al., 2000) falls in the so-called Medieval Warm Period (MWP) popularised by Hubert Lamb (1965) as a period of unusual warmth in Europe and drier-than-average summers in England and Wales.

Interest in Lamb's MWP has typically revolved around its warmth relative to today (e.g. Crowley and Lowery, 2000; Mann and Jones, 2003; Mann et al., 2003) and its global extent (e.g. Hughes and Diaz, 1994; Bradley et al., 2001; Broecker, 2001; Osborn and Briffa, 2006). (See Jansen et al. (2007) for a comprehensive evaluation of the evidence for an MWP and its comparison to today's warming.) However, Stine (1994) pointed out that too much emphasis was being placed on temperature change during the MWP at the expense of evidence for highly unusual hydroclimatic variability at the same time in other parts of the world. He therefore suggested that the MWP moniker be replaced by the more general 'Medieval Climate Anomaly' (or MCA) moniker to avoid prejudicing future palaeoclimatic analyses. This suggestion is now being taken to heart with the growing realization that unusual hydroclimatic variability may be an even more important characteristic of the MCA (Graham et al., 2007; Herweijer et al., 2007; Seager et al., 2007a).

Past megadroughts, both during and subsequent to the MCA period (defined here as falling principally in the AD 900-1300 period; Cook et al., 2004), have been reported now over much of the USA since the work of Douglass $(1929,1935)$ and Stine (1994) (e.g. Grissino-Mayer, 1996; Laird et al., 1996; Cronin et al., 2000; Stahle et al., 2000; Benson et al., 2002; Mason et al., 2004; Yuan et al., 2004; Pederson et al., 2005; Booth et al., 2006). However, the joint temporal and spatial properties of these megadroughts were not adequately described until the development of the North American Drought Atlas (NADA; Cook and Krusic, 2004). The NADA is a set of annually resolved summer (June-August) PDSI reconstructions from tree rings estimated on a 286 -point $2.5^{\circ} \times 2.5^{\circ}$ regular grid that covers most of North America (Fig. 4(a)) (see Cook et al., 1999, for the basic methodology used to develop the reconstructions for the NADA). Depending on the region of the grid, the PDSI reconstructions in the NADA are several centuries to a millennium or more in length, with the majority of the longest reconstructions extending back through the MCA being found in the West (the area within the irregular polygon in Fig. 4(a)).

Cook et al. (2004) transformed the gridded summer PDSI reconstructions in the irregular polygon into estimates of area affected by drought each year (DAI based on a PDSI $<-1$ threshold as before) and produced the time series shown in Fig. 4(b) (redrawn from Cook et al., 2004). While the annual values indicated in Fig. 4(b) are important for understanding the details of drought history over the West, the real story is expressed in the solid black curve (60-year low-pass filtered DAI). The MCA period stands out clearly this way as an extended period of elevated aridity over the West that has not been matched since AD 1300. The horizontal red and blue lines show the difference in DAI between the MCA and the 20th century up through 2003. The difference between those means is highly significant $(P<0.001)$ and translates into a $41 \%$ increase in area affected by drought in the West during the MCA relative to the 20th century (Cook et al., 2004). All of this happened prior to the strong greenhouse gas warming that began with the Industrial Revolution, but perhaps similar to today also during a period of above-average warmth in the West (the MWP; Lamb, 1965; LaMarche, 1974). However, as for the case of future drying, it is probable that the megadroughts were driven by a decrease in precipitation. Higher temperatures, for which there is only tenuous evidence in the West during the MCA, could contribute by increasing evaporative demand and reducing soil moisture, but are unlikely to be able to create megadroughts acting alone. While model projections of future drying and MCA megadroughts may be comparable in the hydrological sense, they have different causes. Future drying in the models is a consequence of overall global warming and how it impacts the atmospheric circulation and hydrological cycle, but there is no evidence that the MCA was a time of global warming of strength comparable to the current day or model projections of the current century. Proxy records indicate a cold MCA in the tropical Pacific Ocean (Cobb et al., 2003) as well. While that is also a characteristic of the 21 st-century drought (Seager, 2007), it is not clear from the models whether this pattern will persist in the future (Vecchi et al., 2008).

The NADA has transformed our understanding of past droughts over much of North America, but there are ways that it 

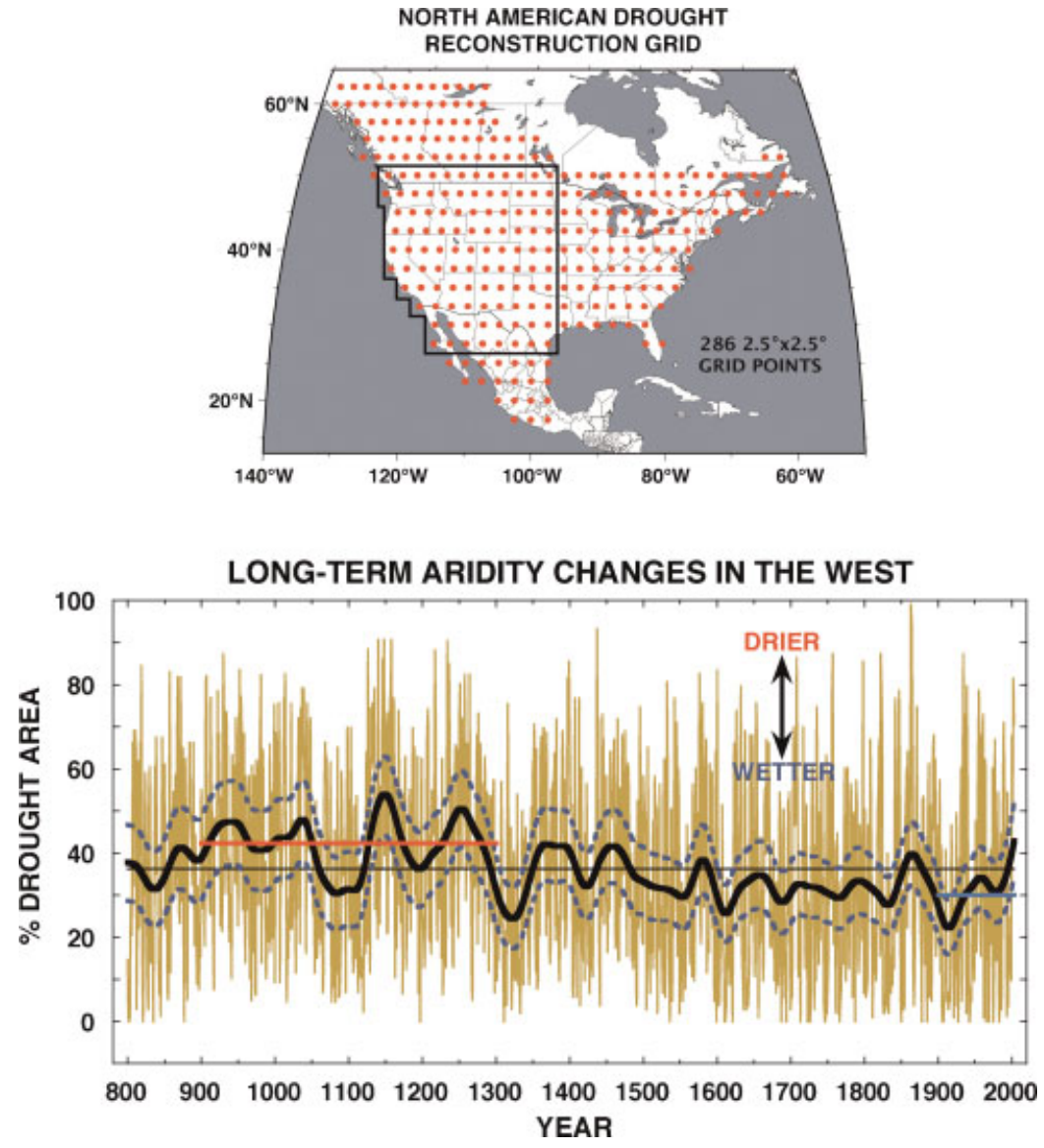

Figure 4 Long-term aridity changes in the West as reported by Cook et al. (2004). The top figure shows the overall map covered by the North American Drought Atlas and the area inside the irregular polygon referred to as the West. The bottom figure shows the Drought Area Index (DAl; percent area covered by PDSI $<-1$ each year) over time in the West as reconstructed by tree rings, both annual in pale brown and 60-year low-pass filtered in black. The dashed blue curves are two-tailed 95\% confidence intervals for the latter. The red and blue lines are mean DAI for the MCA (ca. AD 900-1300) and the 20th century out to 2003, respectively. This record shows that the MCA (ca. AD 900-1300) was much more arid on average than the 20th century. Redrawn from Cook et al. $(2004,2007)$

can be significantly improved. For example, it would be useful to:

- have more complete coverage over North America at far higher spatial resolution to better quantify the spatial properties of drought back in time;

- improve the tree ring network used for reconstruction to provide better and longer drought reconstructions extending back into the MCA period at the majority of the grid points;

- make the instrumental data grid 'living' so that the grid can be seamlessly updated as new data arrive;

- keep the drought reconstructions current by 'blending' them with the instrumental data to enable operational drought monitoring and assessment.

All of these desirable features are now being incorporated in the new 'Living Blended Drought Atlas' (LBDA), which is nearing completion. Figure 5 shows maps of the original NADA (Fig. 5(a)) and the new LBDA (Fig. 5(b)). The increases in spatial coverage, grid resolution and number of tree ring chronologies used are substantial. In addition, mechanisms for continuously updating the instrumental data are now in place.

The instrumental data grid used in the LBDA is based now on 5638 monthly temperature and 7848 monthly precipitation station records from the USA, Canada and Mexico that have all been checked for outliers and the temperature data biasadjusted where needed. Gridded monthly normals were created from the station normals using trivariate thin-plate spline interpolation using the ANUSPLIN program (Hutchinson, 1995). Monthly temperature and precipitation anomalies from the normals of each station were gridded using inverse distance interpolation. The gridded normals and anomalies were then added together to produce the gridded fields of temperature and precipitation data for each month and year. The monthly PDSIs used here for reconstruction were then calculated using the temperature and precipitation fields and soil moisture field capacity estimates from Dunne and Willmott (1996, 2000).

The new gridded summer PDSI reconstructions for the LBDA were developed from the tree ring network (Fig. 5(b)) using the 'point-by-point regression' procedures described in Cook et al. (1999). The calibration period used for developing the regression-based transfer functions was 1928-1978 and the verification period for testing the accuracy of the tree ring estimates was 1895-1927. The calibration and verification tests reported here are typical of those used for assessing the quality of dendroclimatic reconstructions (e.g. Michaelsen, 1987; Meko, 1997; Cook et al., 1999): CRSQ (calibration period coefficient of multiple determination or $R^{2}$ ), CVRE (calibration period reduction of error calculated by leave-one-out crossvalidation), VRSQ (verification period square of the Pearson correlation or $r^{2}$ ), VRE (verification period reduction of error) and VCE (verification period coefficient of efficiency). As such, they can be interpreted as expressions of shared variance 

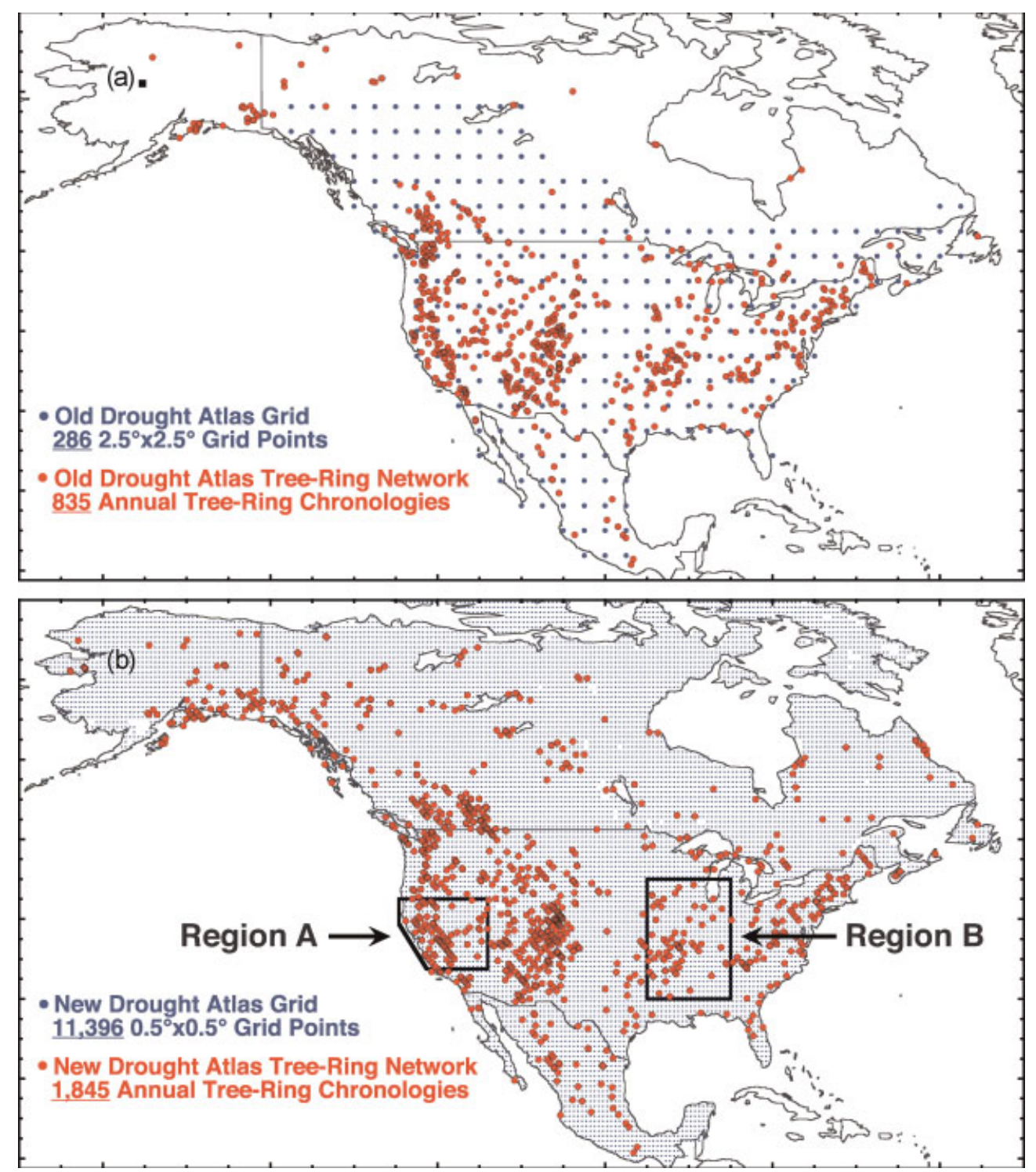

Figure 5 The old NADA drought grid and tree ring network (a) vs. the new LBDA drought grid and tree ring network (b). The California-Nevada (Region A) and the Mississippi Valley (Region B) areas examined for megadroughts are indicated. See the text for details

between the actual data and the tree ring estimates. However, unlike CRSQ, which can never be negative, CVRE, VRSQ (by retaining the sign of $r$ after squaring), VRE and VCE can also have negative values, indicating that there is no skill in the estimates.

Maps showing the calibration and verification results over the full North American grid are shown in Fig. 6. Only CVRE is shown for the calibration period because it is a more conservative and less biased expression of goodness-of-fit. White areas in the grid indicate places where calibration and/or verification failed (CVRE $<0$, VRSQ with $P>0.10, \operatorname{VRE}<0$, $\mathrm{VCE}<0)$. Assessing 'true' failure in the verification period is more difficult to determine, however, because the number of the meteorological stations reporting temperature and precipitation data used for calculating PDSI declines markedly prior to 1930 over large areas of northern Canada, Alaska and Mexico. For this reason, all reconstructions are left in the LBDA with the belief that the quality of some may be higher than their verification statistics indicate.

The calibration map indicates that $95 \%$ of the grid points achieved a CVRE $>0$, with a median value of 0.29 . For VRSQ, VRE and VCE, the percent successful outcomes decreased to $59 \%($ median $\mathrm{VRSQ}=0.23), 53 \%($ median $\mathrm{VRE}=0.21)$ and
$39 \%$ (median $\mathrm{VCE}=0.20$ ), respectively. However, performance is geographically variable, with Alaska and western Canada verifying reasonably well. When the region is restricted to the $30-50^{\circ} \mathrm{N}$ latitude band, where almost all grid points successfully calibrate and verify, median CVRE, VRSQ, VRE and VCE all increase, to $0.43,0.33,0.31$, and 0.27 , respectively. These values are comparable to those reported by Cook et al. (1999) for the coterminous USA only.

\section{Regional examples of megadroughts in the new Living Blended Drought Atlas}

Two examples of how the new LBDA can inform us more completely about the temporal and spatial properties of past Medieval megadroughts over North America will be shown next. The geographic areas chosen are also located in Fig. 5(b): California-Nevada (A) and the Mississippi Valley (B). The former will revisit the Stine droughts and show how the new drought atlas can provide detailed insights into the temporal and spatial properties of drought and wetness 


\section{TREE-RING RECONSTRUCTED DROUGHT CALIBRATION \& VERIFICATION STATISTICS}
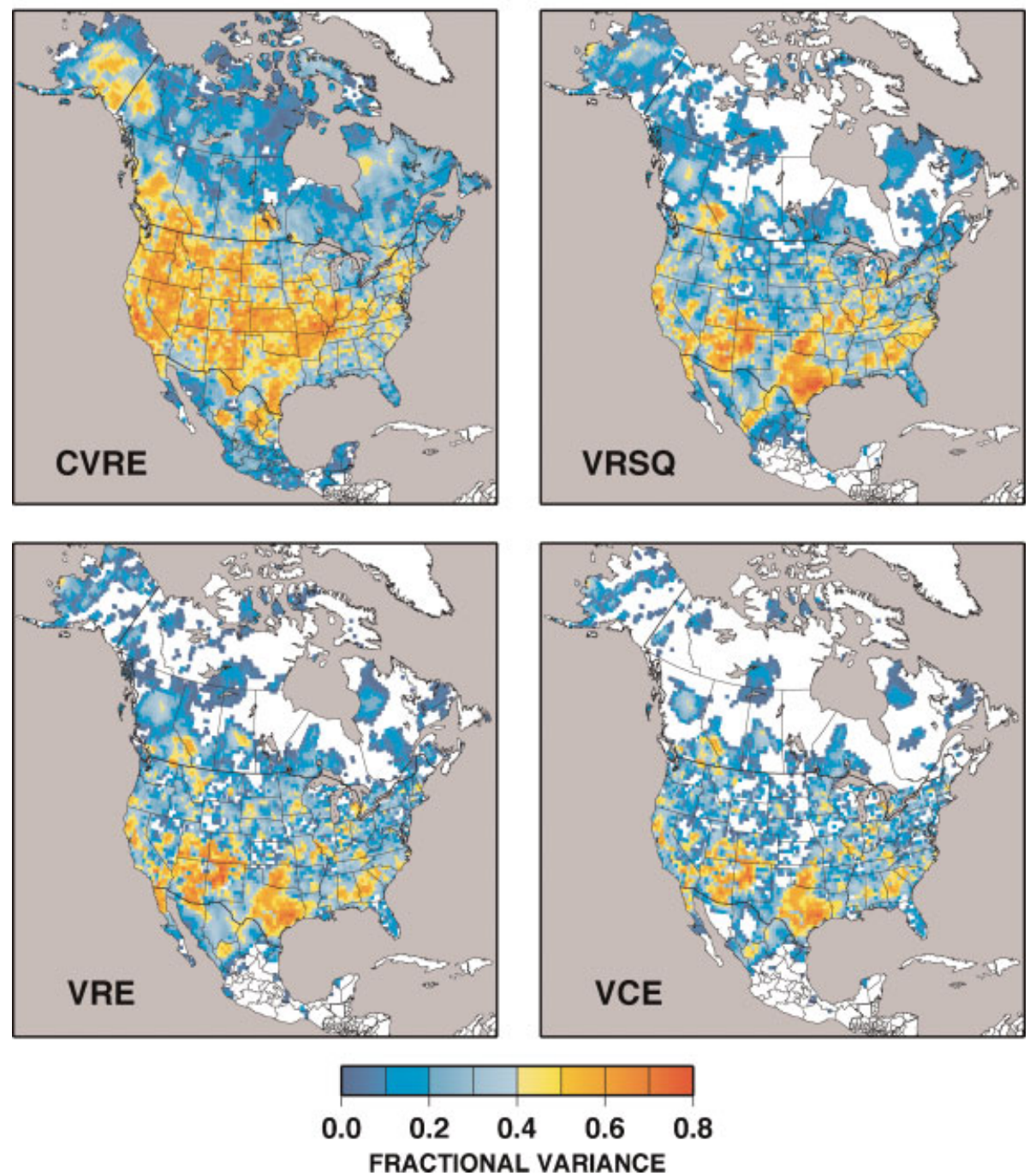

Figure 6 Calibration and verification maps for the new Living Blended Drought Atlas. The CVRE map is for the calibration period (1928-1978) and the VRSQ, VRE and VCE maps are for the verification period (1895-1927). Areas of white indicate regions with no meaningful calibration and/or verification. See the text for details

over North America associated with those events. The latter will examine a geographically and climatically different area located more so in the agriculturally important US Midwest. As shown previously by Stahle et al. (2007) in the old NADA, this area too has experienced megadroughts in the past.

For each geographic area, the mean reconstruction will also be compared to the mean instrumental data for the calibration and verification periods to provide some level of confidence in the fidelity of the reconstruction (cf. Stahle et al., 2007). Note that the data in the reconstructions will be all instrumental after 1978, in keeping with the living property of the LBDA. The reconstructions have also been rescaled to recover lost variance due to regression. This enables them to be directly blended with the instrumental data after 1978. The calibration and verification tests are the same as described above, only here they have been calculated for both the annual and 10-year low-pass filtered data. No reduction in degrees of freedom due to smoothing has been determined because the tests on the filtered data are being made strictly for qualitative comparison to those based on the annual data.

\section{Region A: California-Nevada}

California-Nevada (Region A; Fig. 5(b)) contains the area affected by the two exceptional Stine (1994) droughts. As stated earlier, these droughts lasted more than two centuries before AD 1112 and more than 140 years before AD 1350 (each end date \pm 50 years, $1 \mathrm{SD}$ ), separated by a wet period that presumably killed the trees (by drowning of the roots) established during the first drought period. Since the reconstructions in the LBDA over California-Nevada all extend back to the BC-AD boundary, we can independently determine the timing and duration of these remarkable megadroughts now.

The mean reconstruction is compared to the mean instrumental series for the calibration (1928-1978) and verification (1895-1927) periods in Fig. 7(a). The number of half-degree grid points contained within this grid box is 253 . It is clear that the annual tree ring estimates averaged over the box match the actual data extremely well in both the calibration $\left(R^{2}=0.79\right.$, $C V R E=0.78)$ and verification $\left(r^{2}=0.52, R E=0.48, C E=0.45\right)$ periods. The filtered data match even better $\left(R^{2}=0.90\right.$, $\left.\mathrm{CVRE}=0.89, r^{2}=0.84, \mathrm{RE}=0.78, \mathrm{CE}=0.71\right)$. These results 

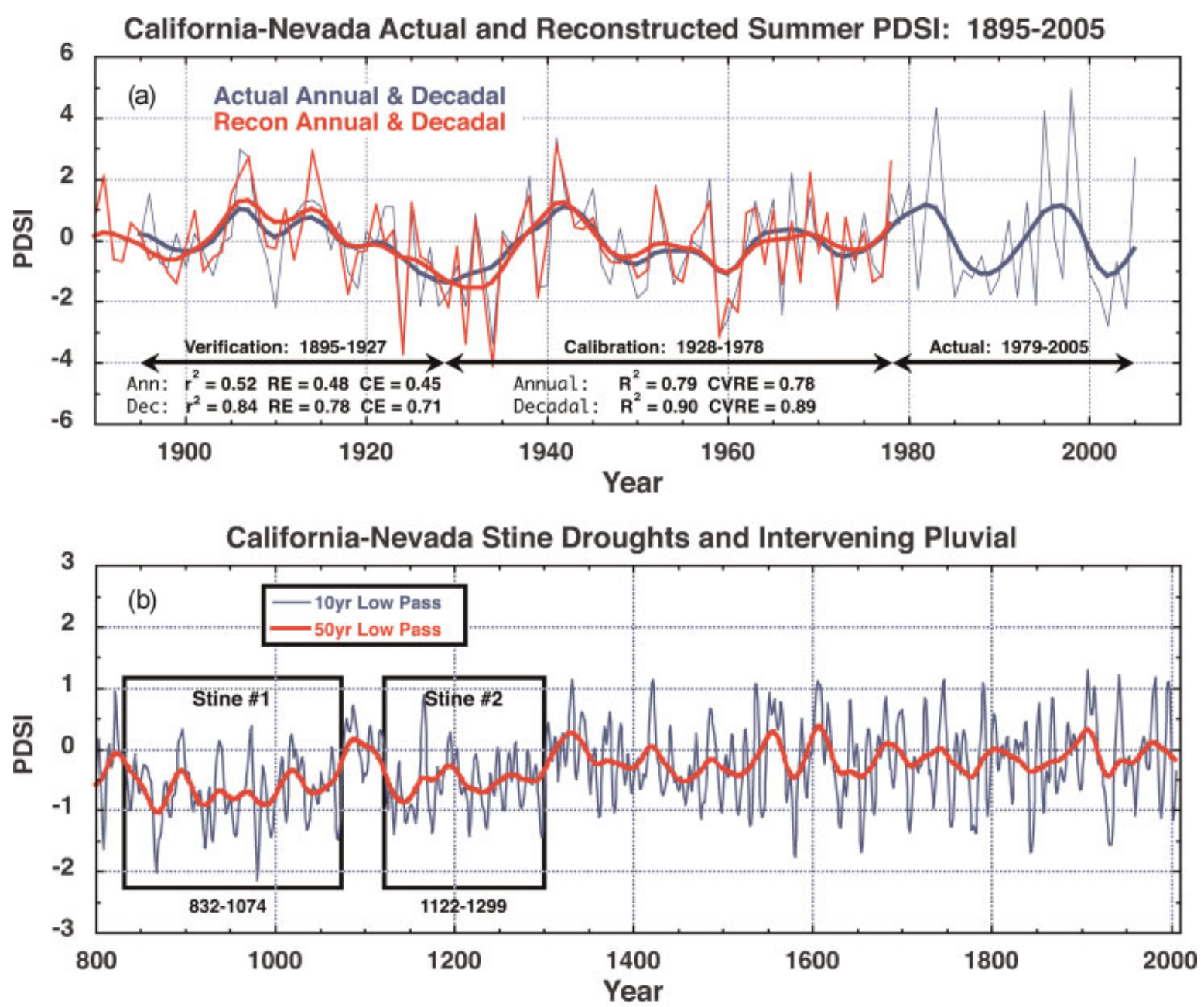

Stine \#1 Megadrought
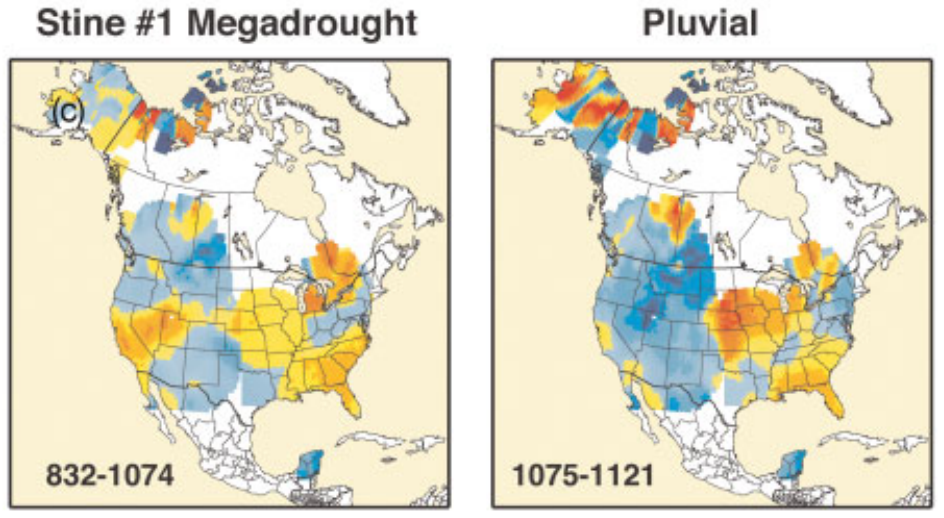

Stine \#2 Megadrought

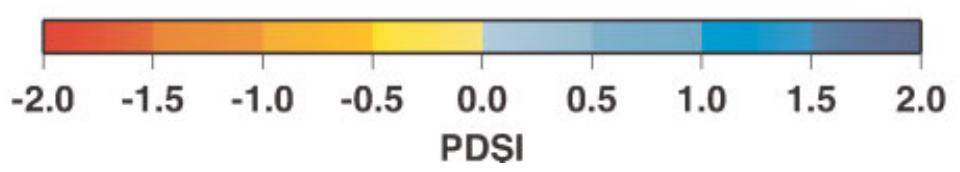

Figure 7 California-Nevada drought as reconstructed from tree rings in the new living blended drought atlas. The upper graph shows the mean actual vs. mean estimated drought over the area shown in Fig. 5(b). The middle graph shows the mean reconstruction from AD 800 to 2005 with the suggested time period of the two Stine megadroughts. The lower graph shows the maps of PDSI for the Stine megadrought periods and the intervening pluvial. See the text for details

lend confidence to the interpretation of the full record as a reliable series of past drought over California and Nevada.

Figure $7(\mathrm{~b})$ shows the mean reconstruction just back to $A D$ 800 after being 10-year and 50-year low-pass filtered to emphasize the occurrence of megadroughts. In so doing, it is possible to pick out the likely intervals covered by the two Stine droughts (Stine no. 1: AD 832-1074; Stine no. 2: AD 11221299) and the intervening pluvial (AD 1075-1121) that killed the first group of trees. These dates enclose those determined by Graham and Hughes (2007) (AD 900-1009 and AD 11761274) for more geographically targeted reconstruction of the Mono Lake Medieval low stands based on a one grid point reconstruction from the original NADA located at $37.5^{\circ} \mathrm{N}$, $120^{\circ} \mathrm{W}$. These differences are not necessarily in conflict, however, because the estimated timing of the Mono Lake low stands may simply be reflecting the driest subperiods within the 
two more geographically extensive megadrought epochs over California and Nevada. While the start and end dates assigned here to the Stine droughts may not be exact, they fall within the radiocarbon uncertainties of Stine's original termination dates (AD 1112 and AD $1350 \pm 50,1$ SD) and have durations (243 and 178 years) consistent with those reported by Stine ( $>200$ and >140 years). The pluvial sandwiched between the two droughts is consequently determined here to have lasted 47 years.

Figure 7(c) shows the spatial patterns of drought and wetness over most of North America during the Stine drought and pluvial epochs. Each drought shows protracted dryness over California and Nevada as expected, with the footprint of the first drought being more spatially restricted there. In both cases, the overall pattern of PDSI is remarkably similar, with wet conditions in the US Northwest and Canada, the southern Great Plains and the Northeast, and dry conditions in the Mississippi Valley, Central Great Plains and Southeast. The spatial similarities between the two Stine drought maps suggest a common set of forcings. In contrast, the pluvial shows a pattern of persistent wetness projecting into California from the northeast, but drought and wetness elsewhere similar to that found during the droughts. Understanding the causes of these remarkable MCA megadroughts during a period of no significant anthropogenic climate forcing (but still in a warmer world perhaps) ought to be a high priority given the model projections of increasing aridity in the Southwest due to anticipated greenhouse warming (Seager et al., 2007b). At the same time, it is just as scientifically interesting to ask what abrupt changes caused the pluvial to begin and end.

It is notable that the spatial patterns associated with the two extended Californian-Nevada droughts are distinctly different from that of the shorter MCA megadroughts such as that at the end of the 13th century, one in the middle of the 12th century and others (Herweijer et al., 2007). These tended to have similar spatial patterns to modern-day droughts and impacted all of Southwestern North America and the Plains with wet conditions to the north. That pattern has been used to argue that the causes of these megadroughts were similar to the causes of the modern droughts: sustained tropical SST anomalies and, in particular, a more La Niña-like state of the tropical Pacific Ocean (Seager et al., 2007a). However, tropical ocean forcing cannot easily explain the continental patterns of North American hydroclimate associated with the California-Nevada extended megadroughts.

\section{Region B: Mississippi Valley}

The Mississippi Valley (Region B; Fig. 5(b)) has not received as much attention as the West regarding past megadroughts. Stahle et al. (2000) described the occurrence of a late 16thcentury megadrought there that may have propagated northward from Mexico. However, relatively few Mississippi Valley tree ring chronologies beginning before AD 1500 were available for PDSI reconstruction in the original NADA. This prompted Stahle et al. (2007) to restrict their examination of megadroughts prior to AD 1500 to the West. An updated version of the original NADA has now been produced on the same $2.5^{\circ}$ grid (NADAv2a; http://www.ncdc.noaa.gov/cgi-bin/ paleo/pd08plot.pl) based on the greatly expanded tree ring network used subsequently in the LBDA. NADAv2a revealed the occurrence of significant 'Mississippian' megadroughts in the 14th and 15th centuries as well (Cook et al., 2007). Given the agricultural and commercial importance of the greater Mississippi Valley region, the new LBDA will be used now to examine in more detail the likely occurrence of megadroughts there over the past millennium.

The mean reconstruction is compared to the mean instrumental series for the calibration and verification periods in Fig. 8(a). The number of half-degree grid points contained within this somewhat larger grid box is 467 . As was the case for California-Nevada, the annual tree ring estimates match the actual data well in both the calibration $\left(R^{2}=0.88\right.$, $\mathrm{CVRE}=0.87)$ and verification $\left(r^{2}=0.70, \mathrm{RE}=0.45, \mathrm{CE}=\right.$ $0.45)$ periods. The filtered data match even better $\left(R^{2}=0.92\right.$, CVRE $\left.=0.91, r^{2}=0.91, R E=0.78, C E=0.77\right)$. These results also lend confidence to the interpretation of the full record as a reliable series of past drought over the Mississippi Valley.

Figure $8(\mathrm{~b})$ shows the mean reconstruction back to AD 900 after being 10-year and 50-year low-pass filtered to emphasise the occurrence of megadroughts, as before. While the mean reconstruction extends back to AD 490, the number of grid points with data over most of the domain only extend back usefully to AD 900. Three megadrought periods are highlighted as likely to have occurred in AD 940-985 (46 years), AD 1100 1247 (148 years) and AD 1340-1400 (61 years). In all three cases, both the 10- and 50-year low-pass filtered curves are below the zero line (indicating drier conditions) for the full periods selected here. These droughts are consistent in timing and duration with inferred megadroughts in the northern Great Plains based on elevated salinity (i.e., reduced rainfall) periods in Moon Lake, Coldwater Lake and Rice Lake in North Dakota (Laird et al., 1996; Fritz et al., 2000). The middle and late period droughts have also been implicated in the collapse of the Cahokia culture in the Mississippi Valley, based on the analysis of the NADAv2a data (Benson et al., 2007, 2009). Other serious droughts in the mid 15th and late 16th centuries previously described by Cook et al. (2007) and Stahle et al. (2007) are also apparent, but will not be addressed further.

Figure 8(c) shows the spatial patterns of these three 'Mississippian' megadroughts that largely fall in the MCA period. Each drought shows protracted dryness over the Mississippi Valley, as expected, with extensions into the southeastern USA and southeastern Canada. The map for AD 1100-1247 also indicates an extension of prolonged drought into the northern Great Plains, consistent with the megadrought reported by Laird et al. (1996) for North Dakota. In contrast, wetter conditions are indicated for parts of the northeastern USA during all three Mississippian megadroughts. However, the spatial pattern in the West changes over time from drier to wetter conditions by the time of the AD 1340-1400 Mississippian megadrought. This suggests that some changes were underway in the coupled ocean-atmosphere system as climate was moving from the MCA period into the cooler Little Ice Age. Again, the spatial pattern associated with the Mississippian megadroughts is different from that associated with typical tropical SST-forced droughts of the instrumental period. The long record also indicates that drought in the agriculturally and commercially important Mississippi Valley has been far worse in the past compared to anything we have experienced over the relatively short instrumental record. This is a justifiable cause for concern.

\section{Causes and implications for the future}

The occurrence of remarkable megadroughts in geographically separate regions of North America during the MCA period and the transition into the Little Ice Age is very troubling. The climate system clearly has the capacity to get 'stuck' in drought- 

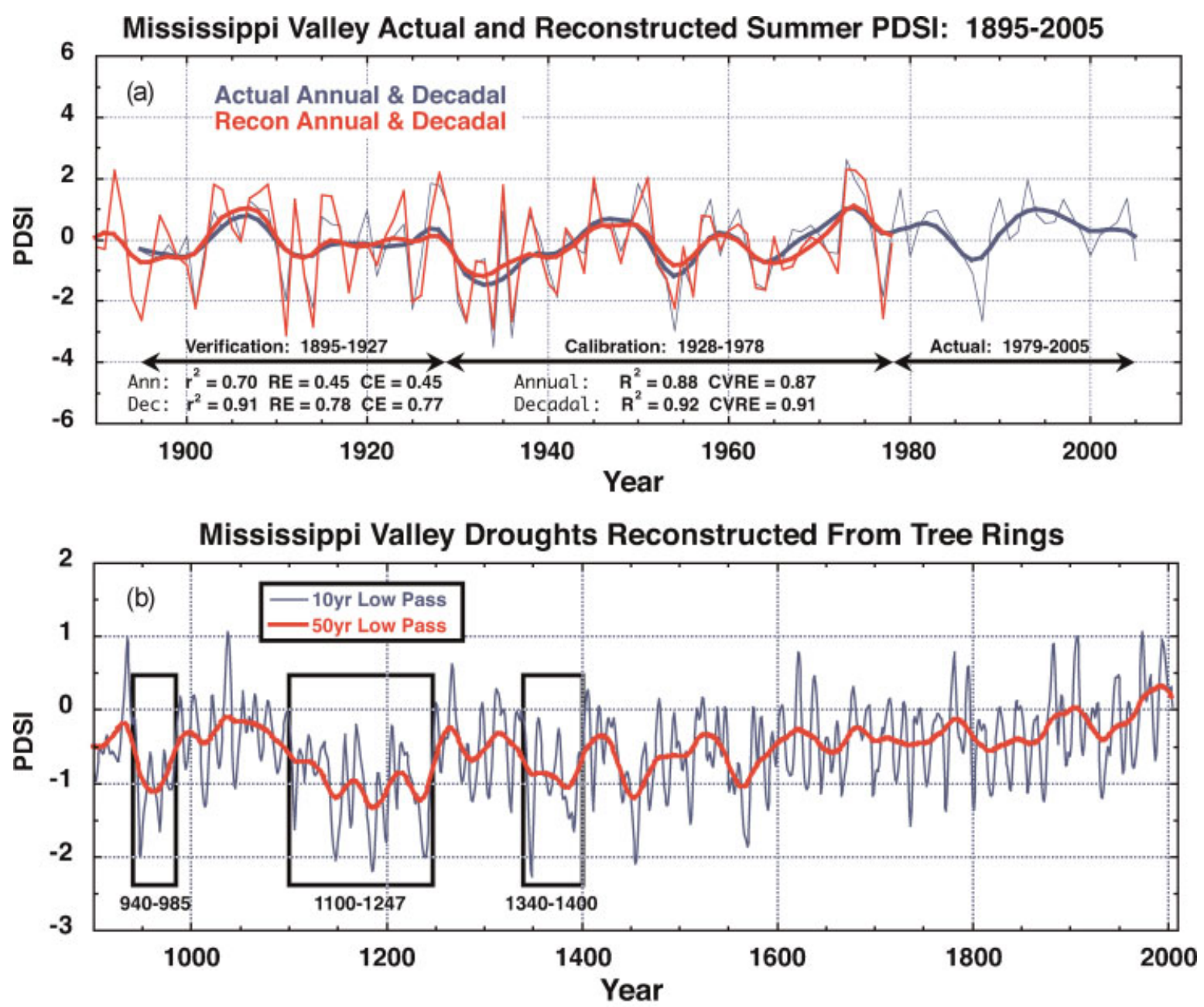

Mississippi Valley Droughts
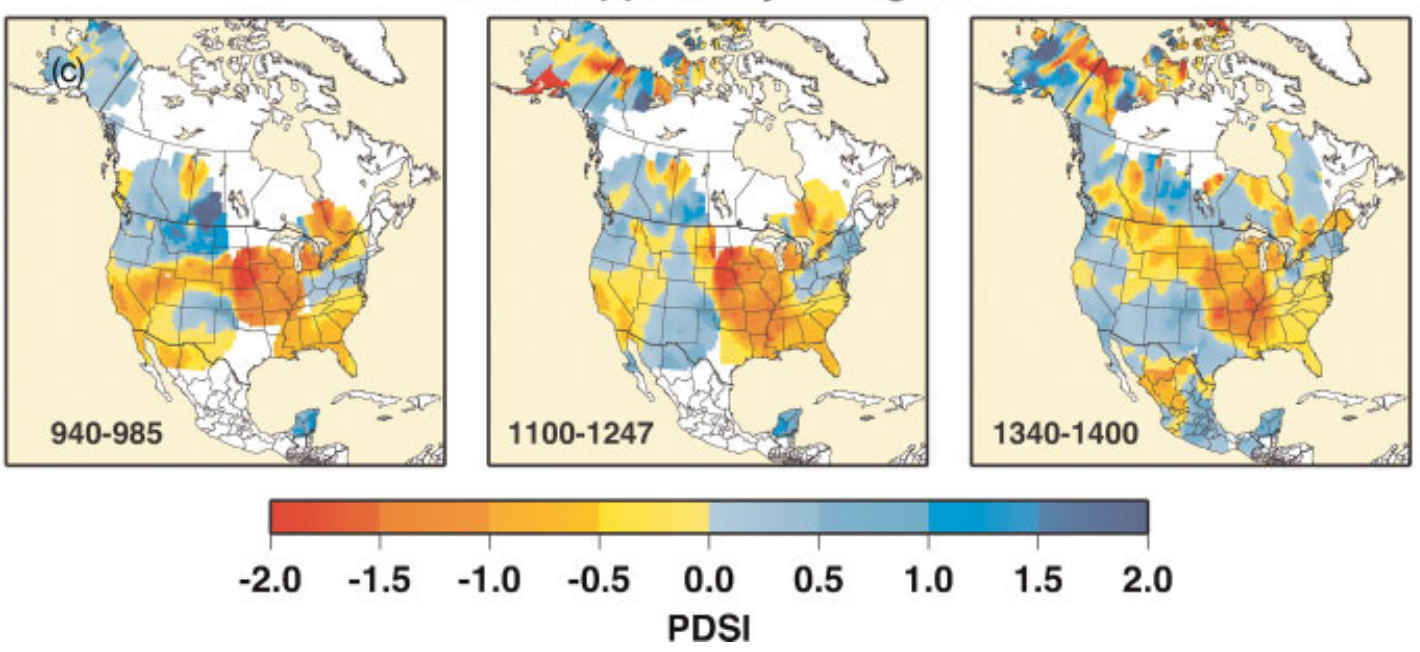

Figure 8 Mississippi Valley drought as reconstructed from tree rings in the new Living Blended Drought Atlas. The upper graph shows the mean actual vs. mean estimated drought over the area shown in Fig. 5(b). The middle graph shows the mean reconstruction from AD 900 to 2005 with three megadrought periods indicated. The lower graph shows the maps of PDSI for the three megadrought periods. See the text for details

inducing modes over North America that can last several decades to a century or more. There is an excellent understanding now that the multi-year historical droughts in the West are frequently linked to cool La Niña-like sea surface temperatures (SSTs) in the tropical Pacific El Niño-Southern Oscillation (ENSO) region (e.g. Cole et al., 2002; Fye et al., 2004; Seager et al., 2005; Herweijer et al., 2006; Cook et al., 2007; Herweijer and Seager, 2008), the turn of the century drought being the most recent example (Seager, 2007). There is also a strong indication that inter-annual drought and wetness in the Mississippi Valley are associated with the state of the North Atlantic Oscillation (NAO) (Fye et al., 2006). Recent modelling studies by Seager et al. (2008a) and Feng et al. (2008) have also tested the influence of both Atlantic and Pacific SSTs on the development of drought in North America. Their results suggest that either a cold tropical Pacific or a warm North Atlantic can produce droughts. Feng et al. (2008) argued that both are probably necessary to produce the intensity and 
longevity of megadroughts in North America. Despite improved understanding of the causes of droughts on the multi-year to decadal timescale, the causes during the Medieval period of multi-decadal droughts grouped together in a period that lasted centuries remain largely unknown.

On longer than multi-year timescales, McCabe et al. (2004) and Huang et al. (2005) have argued that Pacific decadal variability (sometimes called the Pacific Decadal Oscillation (PDO); Mantua et al., 1997) and the Atlantic Multi-decadal Oscillation (AMO; Enfield et al., 2001) are important contributors to the low-frequency modulation of wetness and dryness over North America. Since the PDO (20-30 years) and the AMO (65-80 years) have timescales of variability consistent with the duration of past megadroughts, it is conceivable that they have contributed to the development of those epochs. However, the PDO could also be just a low-frequency version of ENSO (Zhang et al., 1997), so it need not necessarily be an independent contributor to low-frequency drought variability over North America. The AMO may be a different matter based on the modelling results of Sutton and Hodson $(2005,2007)$, Feng et al. (2008) and Seager et al. (2008a), which all showed that warm tropical North Atlantic SSTs can induce drying over western and southern North America. In addition, Dong et al. (2006) suggest that the AMO may even modulate ENSO on multi-decadal timescales via the impact it has on winds over the tropical Pacific Ocean. It remains unclear, however, whether these natural phenomena could give rise to the centennial timescale variations seen in the North American drought record or whether external forcing must be appealed to.

Marine coral records from the core ENSO region of the tropical Pacific also support the concept of decadal and longer ENSO variability during the last millennium (Cobb et al., 2003), with some indication that the MCA period experienced persistent La Niña-like SST conditions that would be drought-inducing over North America. Modelling experiments conducted by Seager et al. (2008b) indicate that tropical Pacific SSTs reconstructed from fossil coral $\delta^{18} \mathrm{O}$ isotope measurements for the 1320-1462 period can produce significant droughts over North America that are consistent with the multidecadal tree ring reconstructed MCA megadroughts within this period in terms of amplitude and spatial pattern. However, the detailed, temporal, model-data match-up was poor, indicating a potential role for forcing from other ocean basins, as suggested by Feng et al. (2008). Further, the cause of this unusual period of cool La Niña-like SSTs during the MCA period is not adequately understood.

Model experiments using the Zebiak-Cane ENSO model (Zebiak and Cane, 1987) forced by a combination of lowfrequency solar irradiance and episodic pulses of explosive volcanism have produced persistent La Niña-like SSTs during the MCA period of strong solar irradiance and weaker volcanism than in the following centuries (Mann et al., 2005; Emile-Geay et al., 2007). One notable event was an interruption of North American drought by an El Niño induced by the massive 1258 eruption (Emile-Geay et al., 2008). The basic mechanism in the Zebiak-Cane model that leads to the development of cool La Niña-like SSTs in response to positive solar forcing is a strong Bjerknes feedback. In the west Pacific warm pool, where the thermocline is deep and upwelling is weak, SSTs warm to balance the stronger solar radiation with increased evaporation. In the eastern equatorial Pacific the SST warming is partially offset by upwelling of cool water in the equatorial Pacific cold tongue. Hence, in response to increased insolation, the west warms by more than the east. This increases the east-west SST gradient, which forces a stronger Walker circulation and sets in motion a positive Bjerknes feedback: as the Walker circulation intensifies, upwelling increases, and the thermocline shoals in the east, which together cause actual cooling of SSTs in the east, i.e. the development of a La Niñalike state. The process by which the Bjerknes feedback creates a La Niña-like response to positive radiative forcing has been described as an 'ocean dynamical thermostat' by Clement et al. (1996) (see also Cane et al., 1997; Cane, 2005).

Enhanced radiative forcing over the tropical Pacific appears to stimulate the dynamical themostat both in modern times (Clement et al., 1996) and in MCA times, based on model experiments (Mann et al., 2005; Emile-Geay et al., 2007). In each case, serious droughts over the West have occurred. This appears not to be a coincidence, but much more still needs to be learned about the coupled ocean-atmosphere conditions during the MCA period before we can be certain. This mechanism for drying of western parts of North America is distinct from that working in model projections of 21st-century climate. The models used in IPCC AR4 do not robustly predict a shift to a more El Niño-like or more La Niña-like state, with some models going one way and others going the other way, but with almost all of them drying the subtropics in general, including southwestern North America. As explained by Held and Soden (2006) and Seager et al. (2007b) the modelprojected drying arises from overall planetary warming and not by any change in the spatial patterns of tropical SSTs. Of course, it is possible that the model projections of tropical SSTs are wrong and that in nature the dynamical thermostat will cause less warming of eastern equatorial Pacific SSTs than elsewhere and create a more La Niña-like ocean state in the current century. However, doubts about how ENSO will change in the future makes any such pronouncement highly uncertain at this time (Cane, 2005; Collins et al., 2005; Vecchi et al., 2008). Further, it is not clear if a shift to a more La Niña-like state in the current century will make drying in southwestern North America, and the subtropics in general, more or less extreme than that induced by overall warming alone.

\section{Conclusions and recommendations}

There is no question now that profound megadroughts have occurred in North America during the last millennium, principally during MCA times and into the early part of the Little Ice Age. These droughts have occurred without any need for enhanced radiative forcing due to anthropogenic greenhouse gas forcing. There are additional model-based results suggesting that the MCA megadroughts were associated with enhanced warming during a time of increased solar irradiance. A 'dynamical thermostat' response to this warming in a model resulted in the development of prolonged La Niña-like SSTs in the eastern tropical Pacific (Mann et al., 2005; Emile-Geay et al., 2007). IPCC model projections also indicate the likelihood that the subtropical dry zones will both dry and expand poleward (Meehl et al., 2007) as warming increases due to greenhouse gas forcing, with the US Southwest becoming increasingly dry in the future (Seager et al., 2007b). While there is no guarantee that the response of the climate system to greenhouse gas forcing will result in megadroughts of the kind experienced by North America in the past, the IPCC model projections are not comforting.

To the degree that drought over large parts of North America is controlled by ENSO, both past and present, the need to know more precisely how ENSO variability and the mean tropical Pacific climate state have changed in the past and will likely change in the future is critically important. Linking together tropical Pacific coral records of past ENSO variability and 
tropical Pacific climate to form a complete annual record of change over the past millennium (Cobb et al., 2003) would greatly enhance our ability to test the linkages between the tropical Pacific and past drought in North America and elsewhere around the globe (Herweijer and Seager, 2008). Current climate model projections of ENSO and the tropical Pacific climate in response to global warming are also too inconsistent and need to be improved (Cane, 2005; Collins et al., 2005; Vecchi et al., 2008). The influence of the North Atlantic SSTs and the AMO on drought over North America also needs to be better understood. Improving the palaeoclimate estimates of past SSTs in the North Atlantic would be an important step in that direction. Finally, expanding the tree ring drought atlas to other parts of the globe will help greatly by providing a more global footprint of past extra-tropical drought for analysis, modelling and hypothesis testing.

Acknowledgements This research was funded in full or in part under the Cooperative Institute for Climate Applications Research (CICAR) award numbers NA03OAR4320179 and NA08OAR4320754 from the National Oceanic and Atmospheric Administration, US Department of Commerce. We also acknowledge the support of the NOAA/NESDIS/ National Climatic Data Center and a grant to RS from the NSF Earth System History program. The statements, findings, conclusions and recommendations are those of the author(s) and do not necessarily reflect the views of the National Oceanic and Atmospheric Administration or the Department of Commerce. Lamont-Doherty Publication Number 7276 .

\section{References}

Andreadis KM, Clark EA, Wood AW, Hamlet AF, Lettenmaier DP. 2005. Twentieth-century drought in the conterminous United States. Journal of Hydrometeorology 6: 985-1001.

Benson L, Kashgarian M, Dye R, Lund S, Paillet F, Smooth J, Kester C, Mensing S, Meko D, Lindström S. 2002. Holocene multidecadal and multicentennial droughts affecting Northern California and Nevada. Quaternary Science Reviews 21: 659-682.

Benson LV, Berry MS, Jolie EA, Spangler JD, Stahle DW, Hattori EM. 2007. Possible impacts of early-11th, middle-12th, and late 13th century droughts on western Native Americans and the Mississippian Cahokians. Quaternary Science Reviews 26: 336-350.

Benson LV, Pauketat TR, Cook ER. 2009. Cahokia's boom and bust in the context of climate change. American Antiquities (in press).

Booth RK, Notaro M, Jackson ST, Kutzbach JE. 2006. Widespread drought episodes in the western Great Lakes region during the past 2000 years: geographic extent and potential mechanisms. Earth and Planetary Science Letters 242: 415-427.

Bradley RS, Briffa KR, Crowley TJ, Hughes MK, Jones PD, Mann ME. 2001. The scope of the Medieval Warming. Science 292: 2011 2012.

Broecker WS. 2001. Was the Medieval Warm Period global? Science 291: 1497-1499.

Cane MA. 2005. The evolution of El Niño, past and future. Earth and Planetary Science Letters 164: 1-10.

Cane MA, Clement AC, Kaplan A, Kushnir Y, Murtugudde R, Pozdnyakov D, Seager R, Zebiak SE. 1997. 20th century sea surface temperature trends. Science 275: 957-960.

Clement AC, Seager R, Cane MA, Zebiak SE. 1996. An ocean dynamical thermostat. Journal of Climate 9: 2190-2196.

Cobb KM, Charles CD, Edwards RL, Cheng H, Kastner M. 2003. El Niño-Southern Oscillation and tropical Pacific climate during the last millennium. Nature 424: 271-276.

Cole J, Overpeck JT, Cook ER. 2002. Multi-year La Niña events and persistent drought in the contiguous United States. Geophysical Research Letters 29: 1647-1650.
Collins M, CMIP Modelling Groups. 2005. El Niño- or La Niña-like climate change? Climate Dynamics 24: 89-104.

Cook ER, Krusic PJ. 2004. North American summer PDSI reconstructions. IGBP PAGES/World Data Center for Paleoclimatology Data Contribution Series No. 2004-045, NOAA/NGDC Paleoclimatology Program, Boulder, CO.

Cook ER, Meko DM, Stockton CW. 1997. A new assessment of possible solar and lunar forcing of the bi-decadal drought rhythm in the western United States. Journal of Climate 10: 1343-1356.

Cook ER, Meko DM, Stahle DW, Cleaveland MK. 1999. Drought reconstructions for the continental United States. Journal of Climate 12: 1145-1162.

Cook ER, Woodhouse C, Eakin CM, Meko DM, Stahle DW. 2004. Longterm aridity changes in the western United States. Science 306: 1015-1018.

Cook ER, Seager R, Cane MA, Stahle DW. 2007. North American drought: reconstructions, causes and consequences. Earth Science Reviews 81: 93-134.

Cronin T, Willard D, Karlsen A, Ishman S, Verardo S, McGeehin J, Kerhin R, Holmes C, Colman S, Zimmerman A. 2000. Climatic variability in the eastern United States over the past millennium from Chesapeake Bay sediments. Geology 28: 3-6.

Crowley TJ, Lowery T. 2000. How warm was the Medieval Warm Period? Ambio 29: 51-54.

Dong B, Sutton RT, Scaife AA. 2006. Multidecadal modulation of El Niño-Southern Oscillation (ENSO) variance by Atlantic Ocean sea surface temperatures. Geophysical Research Letters 33: L08705.

Douglass AE. 1929. The secret of the Southwest solved with talkative tree rings. National Geographic December: 736-770.

Douglass AE. 1935. Dating Pueblo Bonito and other ruins of the Southwest. National Geographic Society Contributed Technical Papers. Pueblo Bonito Series 1: 1-74.

Dunne KA, Willmott CJ. 1996. Global distribution of plant-extractable water capacity of soil. International Journal of Climatology 16: 841859.

Dunne KA, Willmott CJ. 2000. Global distribution of plant-extractable water capacity of soil (Dunne). Dataset. Oak Ridge National Laboratory Distributed Active Archive Center, Oak Ridge, TN http:// www.daac.ornl.gov.

Emile-Geay J, Cane MA, Seager R, Kaplan A, Almasi P. 2007. El Niño as a mediator of the solar influence on climate. Paleoceanography 22: PA3210.

Emile-Geay J, Seager R, Cane MA, Cook ER, Haug GH. 2008. Volcanoes and ENSO over the past millennium. Journal of Climate 21: 3134-3148.

Enfield DB, Mestas-Nuñez AM, Trimble PJ. 2001. The Atlantic multidecadal oscillation and its relation to rainfall and river flows in the continental U.S. Geophysical Research Letters 28: 2077-2080.

Feng S, Oglesby RJ, Rowe CM, Loope DB, Hu Q. 2008. Atlantic and Pacific SST influences on Medieval drought in North America simulated by the Community Atmospheric Model. Journal of Geophysical Research 113: D11101.

Fritz SC, Laird KR, Engstrom DR. 2000. Hydrologic variation in the northern Great Plains during the last two millennia. Quaternary Research 53: 175-184.

Fye F, Stahle DW, Cook ER. 2003. Paleoclimatic analogs to 20th century moisture regimes across the USA. Bulletin of the American Meteorological Society 84: 901-909.

Fye FK, Stahle DW, Cook ER. 2004. Twentieth-century sea surface temperature patterns in the Pacific during decadal moisture regimes over the United States. Earth Interactions 8: 1-22.

Fye FK, Stahle DW, Cook ER, Cleaveland MK. 2006. NAO influence on sub-decadal moisture variability over central North America. Geophysical Research Letters 33: L15707.

Graham NE, Hughes MK. 2007. Reconstructing the Mediaeval low stands of Mono Lake, Sierra Nevada, California, USA. The Holocene 17: 1197-1210.

Graham NE, Hughes MK, Ammann CM, Cobb KM, Hoerling MP, Kennett DJ, Kennett JP, Rein B, Stott L, Wigand PE, Xu T. 2007. Tropical Pacific-mid latitude teleconnections in medieval times. Climatic Change 83: 241-285. 
Grissino-Mayer HD. 1996. A 2129-year reconstruction of precipitation for northwestern New Mexico, U.S.A. In Tree Rings, Environment, and Humanity, Dean JS, Meko DM, Swetnam TW (eds). Radiocarbon: Tucson, AZ; 191-204.

Heim RR Jr. 2002. A review of twentieth-century drought indices used in the United States. Bulletin of the American Meteorological Society 83: 1149-1165.

Held IM, Soden BJ. 2006. Robust responses of the hydrological cycle to global warming. Journal of Climate 19: 5686-5699.

Herweijer C, Seager R. 2008. The global footprint of persistent extratropical drought in the instrumental era. International Journal of Climatology 28: 1761-1774.

Herweijer C, Seager R, Cook ER. 2006. North American Droughts of the mid-to-late nineteenth century: a history, simulation and implication for Mediaeval drought. The Holocene 16: 159-171.

Herweijer C, Seager R, Cook ER, Emile-Geay J. 2007. North American droughts of the last millennium from a gridded network of tree-ring data. Journal of Climate 20: 1353-1376.

Huang H-P, Seager R, Kushnir Y. 2005. The 1976/77 transition in precipitation over the Americas and the influence of tropical sea surface temperatures. Climate Dynamics 24: 721-740.

Hughes MK, Diaz HF. 1994. Was there a 'Medieval Warm Period'? Climatic Change 26: 109-142.

Hutchinson MF. 1995. Interpolating mean rainfall using thin plate smoothing splines. International Journal of Geographical Information Systems 9: 385-403.

IPCC. 2007. Climate Change 2007: The Physical Science Basis. Contribution of Working Group I to the Fourth Assessment Report of the Intergovernmental Panel on Climate Change, Solomon S, Qin D, Manning M, Chen Z, Marquis M, Averyt KB, Tignor M, Miller HL (eds). Cambridge University Press: Cambridge, UK.

Jansen E, Overpeck J, Briffa KR, Duplessy J-C, Joos F, MassonDelmotte V, Olago D, Otto-Bliesner B, Peltier WR, Rahmstorf S, Ramesh R, Raynaud D, Rind D, Solomina O, Villalba R, Zhang D. 2007. Palaeoclimate. In Climate Change 2007: The Physical Science Basis. Contribution of Working Group I to the Fourth Assessment Report of the Intergovernmental Panel on Climate Change, Solomon S, Qin D, Manning M, Chen Z, Marquis M, Averyt KB, Tignor M, Miller HL (eds). Cambridge University Press: Cambridge, UK.

Laird KR, Fritz SC, Maasch KA, Cumming BF. 1996. Greater drought intensity and frequency before A.D. 1200 in the Northern Great Plains, U.S.A. Nature 384: 552-554.

LaMarche VC Jr. 1974. Paleoclimatic inferences from long tree-ring records. Science 183: 1043-1048.

Lamb HH. 1965. The early medieval warm epoch and its sequel. Palaeogeography, Palaeoclimatology, Palaeoecology 1: 13-37.

Lawrimore J, Stephens S. 2003. Climate of 2002 Annual Review. NOAA National Climatic Data Center. Report available at http:// Iwf.ncdc.noaa.gov/oa/climate/research/2002/ann/drought-summary.html [2 June 2009].

MacDonald GM, Stahle DW, Diaz JV, et al. 2008. Climate warming and 21st-century drought in southwestern North America. Eos, Transactions of the American Geophysical Union 89: 82.

Mann ME, Jones PD. 2003. Global surface temperatures over the past two millennia. Geophysical Research Letters 30: 1820.

Mann ME, Ammann CM, Bradley RS, Briffa KR, Crowley TJ, Hughes MK, Jones PD, Oppenheimer M, Osborn TJ, Overpeck JT, Rutherford S, Trenberth KE, Wigley TML. 2003. On past temperatures and anomalous late 20th century warmth. Eos, Transactions of the American Geophysical Union 84(27), doi: 10.1029/2003EO270003

Mann ME, Cane MA, Zebiak SE, Clement A. 2005. Volcanic and solar forcing of the tropical Pacific over the past 1000 years. Journal of Climate 18: 447-456.

Mantua NJ, Hare SR, Zhang Y, Wallace JM, Francis RC. 1997. A Pacific interdecadal oscillation with impacts on salmon production. Bulletin of the American Meteorological Society 78: 1069-1079.

Mason JA, Swinehart JB, Goble RJ, Loope DB. 2004. Late Holocene dune activity linked to hydrological drought, Nebraska Sand Hills, USA. The Holocene 14: 209-217.

McCabe GJ, Palecki MA, Betancourt JL. 2004. Pacific and Atlantic Ocean influences on multidecadal drought frequency in the United
States. Proceedings of the National Academy of Sciences 101: 41364141.

McGregor KM. 1985. Drought during the 1930s and 1950s in the central United States. Physical Geography 6: 288-301.

Meehl GA, Stocker TF, Collins WD, Friedlingstein P, Gaye AT, Gregory JM, Kitoh A, Knutti R, Murphy JM, Noda A, Raper SCB, Watterson IG, Weaver AJ, Zhao Z-C. 2007. Global climate projections. In Climate Change 2007: The Physical Science Basis. Contribution of Working Group I to the Fourth Assessment Report of the Intergovernmental Panel on Climate Change, Solomon S, Qin D, Manning M, Chen Z, Marquis M, Averyt KB, Tignor M, Miller HL (eds). Cambridge University Press: Cambridge, UK.

Meko DM. 1997. Dendroclimatic reconstruction with time varying predictor subsets of tree indices. Journal of Climate 10: 687-696.

Michaelsen J. 1987. Cross validation in statistical climate forecast models. Journal of Climate and Applied Meteorology 26: 15891600.

Mitchell JM Jr, Stockton CW, Meko DM. 1979. Evidence of a 22-year rhythm of drought in the western United States related to the Hale solar cycle since the 17th century. In Solar-Terrestrial Influences on Weather and Climate, McCormac BM, Seliga TA (eds). D. Reidel: Dordrecht; 125-144.

Nakicenovic N, Swart R (eds). 2000. Special Report on Emissions Scenarios. Cambridge University Press: New York.

Osborn TJ, Briffa KR. 2006. The spatial extent of 20th-century warmth in the context of the past 1200 years. Science 311: 841-844.

Palmer WC. 1965. Meteorological Drought. Weather Bureau Research Paper 45, US Department of Commerce, Washington, DC.

Pederson DC, Peteet DM, Kurdyla D, Guilderson T. 2005. Medieval Warming, Little Ice Age, and European impact on the environment during the last millennium in the lower Hudson Valley, New York, USA. Quaternary Research 63: 238-249.

Seager R. 2007. The turn of the century North American drought: global context, dynamics and past analogues. Journal of Climate 20: 13531376.

Seager R, Kushnir Y, Herweijer C, Naik N, Velez J. 2005. Modeling of tropical forcing of persistent droughts and pluvials over western North America: 1856-2000. Journal of Climate. 18: 4068-4091.

Seager R, Graham N, Herweijer C, Gordon AL, Kushnir Y, Cook E. 2007a. Blueprints for Medieval hydroclimate. Quaternary Science Reviews 26: 2322-2336.

Seager R, Ting M, Held I, Kushnir Y, Lu J, Vecchi G, Huang H-P, Harnik N, Leetmaa A, Lau N-C, Li C, Velez J, Naik N. 2007b. Model projections of an imminent transition to a more arid climate in southwestern North America. Science 316: 1181-1184.

Seager R, Kushnir Y, Ting MF, Cane M, Naik N, Velez J. 2008a. Would advance knowledge of 1930s SSTs have allowed prediction of the Dust Bowl drought? Journal of Climate 21: 3261-3281.

Seager R, Burgman R, Kushnir Y, Clement AC, Cook ER, Naik N, Miller J. 2008b. Tropical Pacific forcing of North American Medieval megadroughts: testing the concept with an atmosphere model forced by coral-reconstructed SSTs. Journal of Climate 21: 6175-6190.

Stahle DW, Cook ER, Cleaveland MK, Therrell MD, Meko DM, Grissino-Mayer HD, Watson E, Luckman BH. 2000. Tree-ring data document 16th century megadrought over North America. Eos, Transactions of the American Geophysical Union. 81: 121125.

Stahle DW, Fye FK, Cook ER, Griffin RD. 2007. Tree-ring reconstructed megadroughts over North America since AD 1300. Climatic Change 83: $133-149$.

Stine S. 1994. Extreme and persistent drought in California and Patagonia during mediaeval time. Nature 369: 546-549.

Sutton RT, Hodson DLR. 2005. Atlantic Ocean forcing of North American and European summer climate. Science 309: 115-118.

Sutton RT, Hodson DLR. 2007. Climate response to basin-scale warming and cooling for the North Atlantic Ocean. Journal of Climate 20: 891-907.

Svoboda M, LeComte D, Hayes M, Heim R, Gleason K, Angel J, Rippey B, Tinker R, Palecki M, Stooksbury D, Miskus D, Stephens S. 2002. The drought monitor. Bulletin of the American Meteorological Society 83: 1181-1190. http://www.drought.unl.edu/dm/monitor.html [2 June 2009]. 
Vecchi GA, Clement A, Soden BJ. 2008. Examining the tropical Pacific's response to global warming. EOS, Transactions of the American Geophysical Union 89: 81, 83.

Weakly HE. 1965. Recurrence of drought in the Great Plains during the last 700 years. Agricultural Engineering 46: 85.

Woodhouse CA, Overpeck JT. 1998. 2000 years of drought variability in the central United States. Bulletin of the American Meteorological Society 79: 2693-2714.
Yuan F, Linsley BK, Lund SP, McGeehin JP. 2004. A 1200 year record of hydrologic variability in the Sierra Nevada from sediments in Walker Lake, Nevada. Geochemistry, Geophysics and Geosystems 5: Q03007.

Zebiak SE, Cane MA. 1987. A model El Niño-Southern Oscillation. Monthly Weather Review 115: 2262-2278.

Zhang Y, Wallace JM, Battisti DS. 1997. ENSO-like interdecadal variability: 1900-93. Journal of Climate 10: 1004-1020. 